\title{
LA ANATOMÍA OCULAR DURANTE EL SIGLO XVIII
}

\author{
LÓPEZ DE LETONA $C^{1}$
}

Para el estudio del tema que encabeza el presente trabajo podríamos considerar dos períodos distintos: El primero abarca las cinco primeras décadas del siglo y el segundo los otros diez lustros y los comienzos del siguiente

El mejor lugar donde podemos acudir para documentarnos es evidentemente los contenidos de las diversas obras anatómicas editadas durante este período, así el primer tratadista que se refiere a la anatomía ocular es Manuel de Porras en 1716 y años después Martín Martínez.

La obra más sobresaliente de Porras es Anatomía galénico moderna, describe allí las estructuras oculares dentro del apartado denominado genéricamente «Cavidad animal», concepto en el que se incluía también el sistema nervioso central y los órganos de los sentidos. Lo expuesto se ajusta al modo clásico de describir las estructuras anatómicas, supeditándolo todo a la función visiva. En realidad no se aportaba nada novedoso.

Por ello mereció severas críticas del segundo autor antes citado: Martín Martínez, este último es un importante médico de cámara de los primeros Borbones, siendo además examinador del Real Tribunal de Protomedicato y durante un tiempo presidente de la Regia Sociedad de Sevilla, antecesora de las modernas Academias; instituciónes tipicamente francesas importadas aquí por la nueva dinastía borbónica.

Nuestro médico fue en realidad un polemista que se opuso a casi todos los conceptos médicos conocidos hasta entonces, acuñando el término de «Medicina escéptica».

Recoge muchos aspectos interesantes de la morfología ocular en su Anatomía completa del hombre que se editó en 1728, incluyéndose en el texto unos magníficos grabados de Irala; así como en otra obra suya Noches anatómicas particularmente en su segunda edición de 1750 .
Es también digna de reseñarse su Compendio y examen nuevo de la cirugía moderna, allí se vinculan claramente los conceptos anatómicos con los quirúrgicos sobre todo en el apartado titulado «Advertencias necesarias para la cirugía».

Pero estos dos autores exponen de forma más o menos completa los conocimientos existentes respecto a la estructura del ojo sin que probablemente ninguno de ellos viese enfermos oftalmológicos ni menos aun practicase la cirugía ocular.

En este primer período podemos citar también a Blas de Beaumont, cirujano al servicio de Felipe V, sin que sepamos con certeza si entre las intervenciones quirúrgicas que practicó figuraban las oftalmológica, pero sí que expuso sus conocimientos en dos libros: Exercitaciones anatómicas de 1728, y Exercitaciones quirúrgicas, editado algunos años después.

Caso semejante fue el de Juan de Dios López el cual redactó ya mediado el siglo su Compendio anatómico reeditado en 1791. Describe el ojo minuciosamente y como en los autores antes citados completaba sus explicaciones con diversos apuntes referentes a las funciones biológicas oculares.

El panorama cambió en cierta manera a partir de 1760 ya que entonces la cirugía se desarrolló de modo espectacular como consecuencia de los planes de Carlos III que se tradujeron con la fundación de los Reales Colegios de Cirugía de Cádiz, Barcelona y Madrid, vinculados los dos primeros a la Armada.

La obra más importante de este período es sin duda La anatomía del cuerpo humano de la que fueron autores Jaime Bonells e Ignacio Lacaba.

Pero no podemos dejar de lado las opiniones de varias de figuras eclesiásticas vinculadas en cierto modo a la medicina.

De comienzo Lorenzo Hervás y Panduro, jesuita residente en Roma a causa de expulsión en tiempos de Carlos III. Allí redactó en italiano dos obras

1 IOBA. Valladolid. España.

E-mail: berta@ioba.med.uva.es 
importantes: Historia de la vida del hombre y posteriormente $\mathrm{El}$ Hombre fysico, ambas se conocerían en España ya a finales del XVIII.

En la segunda de ellas se recoge cuando se sabía de las estructuras oculares y las funciones visuales.

Sobre este mismo asunto insistirá otra figura importante: El benedictino Benito Jerónimo Feijoo (1676-1764), el cual opinó en muchas ocasiones sobre asuntos médicos en defensa de las ideas de Martín Martínez. Acaso por ello Gregorio Marañón afirmaba que Feijoo fue «Uno de los promotores de la mentalidad moderna científica en España».

Su obra más conocida es Teatro crítico, allí afirmaba que el ojo era un órgano meramente receptor y no emisor, lo que le dio ocasión para criticar, dentro de su línea habitual una de las supersticiones más expendida en todos los tiempos. La existencia del mal de ojo.

En otro lugar de la obra citada nuestro benedictino se refería detenidamente a la impresión visual que tenía lugar en la retina y sobre todo al nervio óptico que llevaba todas las sensaciones recibidas hasta el cerebro.

Del mismo modo el sacerdote Antonio José Rodríguez, el cual en su Palestra científica verifica el simil del sistema nervioso central, incluyendo la vista, con el funcionamiento de un órgano musical. Lo hace de esta forma:

«Las teclas son los sentidos externos ... desde las teclas del órgano natural suben varillas hasta los alambres (nervios). Desde cada uno de los sentidos externos prosigue un nervio hasta internarse dentro del cerebro.»

Como colofón de lo expuesto vemos claramente que los conocimientos anatómicos oculares del XVIII, eran en realidad teóricos si bien resultaban imprescindibles para la práctica de la cirugía, reducida probablemente a la intervención de las cataratas realizada casi siempre por empíricos carentes de conocimientos teóricos. 